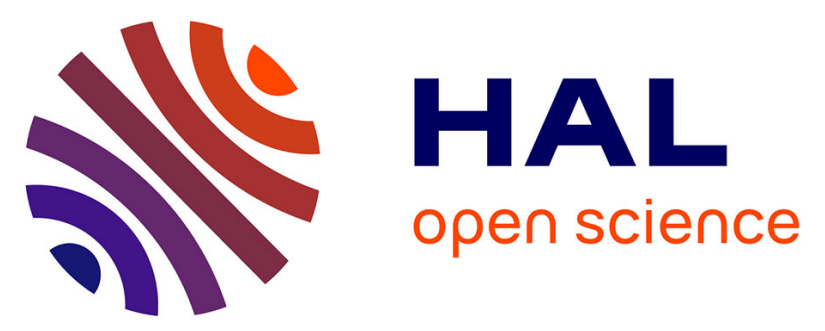

\title{
1H-NMR metabolomics profiling of zebra mussel (Dreissena polymorpha): A field-scale monitoring tool in ecotoxicological studies
}

\author{
Younes Mohamed Ismail Hani, Sophie Prud'homme, Jean-Marc Nuzillard, \\ Isabelle Bonnard, Christelle Robert, Katherine Nott, Sébastien Ronkart, \\ Odile Dedourge-Geffard, Alain Geffard
}

\section{To cite this version:}

Younes Mohamed Ismail Hani, Sophie Prud'homme, Jean-Marc Nuzillard, Isabelle Bonnard, Christelle Robert, et al.. 1H-NMR metabolomics profiling of zebra mussel (Dreissena polymorpha): A field-scale monitoring tool in ecotoxicological studies. Environmental Pollution, 2021, pp.116048. 10.1016/j.envpol.2020.116048 . hal-03100830

\section{HAL Id: hal-03100830 \\ https://hal.univ-lorraine.fr/hal-03100830}

Submitted on 25 Jun 2021

HAL is a multi-disciplinary open access archive for the deposit and dissemination of scientific research documents, whether they are published or not. The documents may come from teaching and research institutions in France or abroad, or from public or private research centers.
L'archive ouverte pluridisciplinaire HAL, est destinée au dépôt et à la diffusion de documents scientifiques de niveau recherche, publiés ou non, émanant des établissements d'enseignement et de recherche français ou étrangers, des laboratoires publics ou privés.

\section{(ㅇ)(1) $\$$}

Distributed under a Creative Commons Attribution - NonCommercial - NoDerivatives $\mid 4.0$ 
$1 \quad{ }^{1}$ H-NMR metabolomics profiling of zebra mussel (Dreissena polymorpha): a field-scale

2 monitoring tool in ecotoxicological studies

3 Authors

4 Younes Mohamed Ismail HANI ${ }^{1,2^{*}}$, Sophie Martine PRUD’HOMME ${ }^{1,3}$, Jean-Marc

$5 \quad$ NUZILLARD $^{4}$, Isabelle BONNARD ${ }^{1}$, Christelle ROBERT ${ }^{5}$, Katherine NOTT $^{6}$, Sébastien

6 RONKART ${ }^{6}$, Odile DEDOURGE-GEFFARD ${ }^{1}$, Alain GEFFARD $^{1}$

7

$8{ }^{1}$ Université de Reims Champagne-Ardenne (URCA), UMR-I O2 SEBIO (Stress

9 Environnementaux et Biosurveillance des milieux aquatiques), Moulin de la Housse, Reims,

10 France.

112 Université de Bordeaux, UMR EPOC 5805, équipe Ecotoxicologie aquatique, Place du Dr 12 Peyneau, 33120 Arcachon, France (present address)

$13{ }^{3}$ Université de Lorraine, CNRS, LIEC, F-57000, Metz, France (present address)

$14{ }^{4}$ Université de Reims Champagne Ardenne, CNRS, ICMR UMR 7312, 51097 Reims, France

$15{ }^{5}$ CERGroupe Marloie, Wallonia, Belgium

$16{ }^{6}$ La société wallonne des eaux, rue de la Concorde 41, 4800 Verviers, Belgium

$17 *$ Corresponding authors:

18 younes.hani@u-bordeaux.fr (permanent address: haniyounes@ hotmail.fr) 


\section{Abstract}

Biomonitoring of aquatic environments requires new tools to characterize the effects of pollutants on living organisms. Zebra mussels (Dreissena polymorpha) from the same site in north-eastern France were caged for two months, upstream and downstream of three wastewater treatment plants (WWTPs) in the international watershed of the Meuse (Charleville-Mézières "CM" in France, Namur "Nam" and Charleroi "Cr" in Belgium). The aim was to test ${ }^{1} \mathrm{H}-\mathrm{NMR}$ metabolomics for the assessment of water bodies' quality. The metabolomic approach was combined with a more "classical" one, i.e., the measurement of a range of energy biomarkers: lactate dehydrogenase (LDH), lipase, acid phosphatase (ACP) and amylase activities, condition index (CI), total reserves, electron transport system (ETS) activity and cellular energy allocation (CEA). Five of the eight energy biomarkers were significantly impacted (LDH, ACP, lipase, total reserves and ETS), without a clear pattern between sites (Up and Down) and stations (CM, Nam and Cr). The metabolomic approach revealed variations among the three stations, and also between the upstream and downstream of Nam and CM WWTPs. A total of 28 known metabolites was detected, among which four (lactate, glycine, maltose and glutamate) explained the observed metabolome variations between sites and stations, in accordance with chemical exposure levels. Metabolome changes suggest that zebra mussel exposure to field contamination could alter their osmoregulation and anaerobic metabolism capacities. This study reveals that lactate is a potential biomarker of interest, and ${ }^{1} \mathrm{H}-\mathrm{NMR}$ metabolomics can be an efficient approach to assess the health status of zebra mussels in the biomonitoring of aquatic environments.

Keywords: active biomonitoring, Dreissena polymorpha, energy metabolism, metabolomics,

\section{${ }^{1} \mathrm{H}$ NMR}

Caption: Results of this study showed the interest of ${ }^{1} \mathrm{H}-\mathrm{NMR}$ metabolomics as an efficient approach in biomonitoring of aquatic environments, and lactate could be a potential biomarker. 
According to the European Environment Agency, point and diffuse source pollutions are the main pressures affecting over $55 \%$ of the European surface water bodies (EEA, 2018). Among European water policies, the Water Framework Directive (WFD) (2000/60/EC) is considered as a pioneer framework for the monitoring and protection of aquatic environments, combining chemical and ecological approaches. These approaches are efficient but insufficient when it comes to relating water pollutant bioavailability to impacts on aquatic organisms and ecosystems, which underlines the need to develop new multidisciplinary tools to support and improve current approaches for biomonitoring aquatic environments (Wernersson et al., 2015).

In this context, several approaches promoted by scientific communities are largely used in ecotoxicology. For example, biomarkers (Amiard-Triquet et al., 2012; Arrighetti et al., 2019; Catteau et al., 2019) are indicators of several biological functions (immune system, reproduction, growth, metabolism, etc.). They have long been used in ecotoxicological studies, within a multi-parametric approach, and should ultimately be integrated as complementary tools into regulatory biomonitoring approaches such as the WFD (Adams et al., 2001; Arrighetti et al., 2019; Milinkovitch et al., 2019; Sanchez and Porcher, 2009). More recently, new biological approaches related to modern analytical techniques (e.g., "-omics” approaches) have received special attention from ecotoxicology researchers because they can provide reliable information at very low levels of biological organization (Aggelen et al., 2010; Brockmeier et al., 2017).

Metabolomics is one of the recent "-omics" techniques with a large range of applications (Viant, 2007). It relies on the detection of small polar molecules called metabolites (molecular mass 50-2,000 Da) in different samples (biological fluids, cells, tissues, organs, organisms). This approach targets primary metabolites (sugars, amino acids) essential to 
various biological functions of a living organism (e.g., growth, reproduction), as well as specialized metabolites (alkaloids, flavonoids) involved in the interactions of organisms with their environment (Nicolè and Thomas, 2017). All these molecules form "the metabolome" which is the result of gene expression and the end-products of the metabolism. It characterizes the interactions of organisms with their environment, and makes metabolomics an emerging and promising approach in environmental science (Bundy et al., 2008; Nicolè and Thomas, 2017).

Metabolomic studies can be performed using different analytical techniques, such as mass spectrometry (MS) (Courant et al., 2014) and nuclear magnetic resonance spectroscopy (NMR) (Watanabe et al., 2015). Proton nuclear magnetic resonance ( $\left.{ }^{1} \mathrm{H}-\mathrm{NMR}\right)$ spectroscopybased metabolomics is a commonly used tool for studying the effects of pollutants on the metabolic profiles of aquatic organisms, in laboratory or field-scale conditions (Cappello et al., 2017, 2016, 2013; Jones et al., 2008; Kwon et al., 2012; Maisano et al., 2017; Tuffnail et al., 2009; Xu et al., 2019). Because the spectral peak areas are quantitatively related to metabolite concentrations, this technique simultaneously provides unbiased and reproducible data about a wide range of metabolites. Furthermore, ${ }^{1} \mathrm{H}-\mathrm{NMR}$ has several other advantages, in that it is a rapid and cost-effective analytical technique that detects relative changes in the spectral pattern of a tissue / organ or even whole tissue extract, and can reflect biological effects of known and unknown environmental stressors on organisms (Tikunov et al., 2010). The potential of this technique to unveil the modes of action of environmental stressors and to identify possible biomarkers in ecotoxicology has been reported in a recent, detailed and comprehensive review covering NMR-based metabolomics research studies conducted to date on aquatic organisms (Cappello, 2020). 
Despite the many upsides of biomarker and metabolomic approaches, downsides exist

too. The main drawback is the possible interference of biological responses to stress conditions with other confounding factors, leading to false positive results or to background noises that can mask the real effect of chemical substances (false negative results) (Forbes et al., 2006).

The variability of these biological parameters can be attributed to extrinsic abiotic factors (e.g., temperature, salinity) or to intrinsic biotic factors (e.g. genotype, gender, age, reproduction) (Benito et al., 2019; Beyer et al., 2017; Freitas et al., 2019; Hines et al., 2007; Nam et al., 2017). All these factors can be species-, time-, and space-dependent; therefore, they are difficult or even impossible to control in the field, and their use may be limited in biomonitoring studies. To address this problem, some authors have proposed to work under semi-controlled field conditions (controlled provenance, sex, size, etc.) while keeping natural environmental complexity, by caging organisms in aquatic environments that they naturally inhabit or not (Catteau et al., 2019; Kerambrun et al., 2016; Le Guernic et al., 2016).

Zebra mussels (Dreissena polymorpha) originate from the Ponto-Caspian region and are largely used as an animal model in aquatic ecotoxicology because (1) they are largely distributed in the freshwater ecosystems of the northern hemisphere, (2) are considered as one of the worst invasive species in the world, (3) occur at high densities, which facilitates their use for ecotoxicological tests without fear of causing damage to their sustainability (4) their high filtration capacities cause them to accumulate high levels of pollutants, and (5) they tolerate environmental stressors well (Binelli et al., 2015; Bourgeault et al., 2010; Karatayev et al., 2012; Louis et al., 2019). Except for a few studies, all scientific articles about the use of the zebra mussel in ecotoxicology have focused on classical biomarkers such as immunity, oxidative stress, energy metabolism, genotoxicity biomarkers, etc. (Binelli et al., 2009; Lafontaine et al., 2000; Minguez et al., 2012; Minier et al., 2006; Quinn et al., 2011). Although the zebra mussel is a valuable bioindicator species in aquatic biomonitoring, few researchers 
126 (Leprêtre et al., 2019; Péden et al., 2019; Watanabe et al., 2015) have addressed the application

127 of "-omics" approaches, especially metabolomics (Watanabe et al., 2015), to this model 128 organism.

An ${ }^{1} \mathrm{H}-\mathrm{NMR}$ metabolomic assay was developed in our laboratory for $D$. polymorpha

130 (Prud'homme et al., 2020). The present study addresses the application of this approach to the

131 analysis of the whole-body metabolome of $D$. polymorpha in an active field-scale

132 biomonitoring study. Zebra mussels collected from the same site were caged for two months,

133 upstream and downstream of three wastewater treatment plants (WWTPs) in the watershed of

134 the Meuse river (Charleville-Mézières in France, Namur and Charleroi in Belgium). The aim

135 was to determine whether we could identify metabolic profile differences among the three

136 stations (interstation effects), and between the upstream/downstream locations of each

137 experimental station (intrastation effects). Additionally, energy metabolism core biomarkers

138 were measured, with a view to proposing the metabolomic approach as a complementary tool

139 for diagnosing and monitoring the chemical quality of European water bodies.

140 2. Materials and methods

\subsection{Experimental design}

Zebra mussels ( $2 \pm 0.1 \mathrm{~cm}$ shell length) were collected in October 2018 from the "Lac

143 du Der-Chantecoq" (northeastern France, 445'00" E; 48³4'00" N). After a two-week

144 acclimation period in aerated laboratory tanks, mussels were randomly placed in 2-mm-mesh

145 polyethylene cages $(7 \times 7 \times 14 \mathrm{~cm})(200$ mussels per cage $)$, that were installed for two months

146 upstream (1 cage) and downstream (1 cage) of three WWTPs which treat the water of three

147 municipalities: (1) Charleville-Mézières (France), (2) Charleroi and (3) Namur (Belgium)

148 (Figure 1). In Namur, a third cage was installed in a supplementary upstream point, $5 \mathrm{~km}$ ahead 
149 of the Meuse-Sambre confluence, and called Nam-Upstream1. For each station, cages were 150 positioned 40 to $100 \mathrm{~m}$ apart, except in Charleroi where they were about $2 \mathrm{~km}$ away from each

151 other. In total, 7 experimental cages were ballasted and placed in the same way at about $1.0 \mathrm{~m}$

152 depth on natural rocky structures of 7 experimental sites: 1- Charleville-Mèzières upstream

153 (CM-Upstream), 2- Charleville-Mézières downstream (CM-Downstream), 3- Charleroi

154 upstream (Cr-Upstream), 4- Charleroi downstream (Cr-Downstream), 5- Namur upstream1

155 (Nam-Upstream1), 6- Namur upstream2 (Nam-Upstream2) and 7- Namur downstream (Nam-

156 Downstream). The GPS coordinates and water physico-chemical parameters of each site,

157 recorded at the beginning and the end of the experiment, are reported in Table 1. Besides, water 158 samples were collected at least 2 times per month and per site (at the beginning and at the end 159 of the month) for chemical analysis.

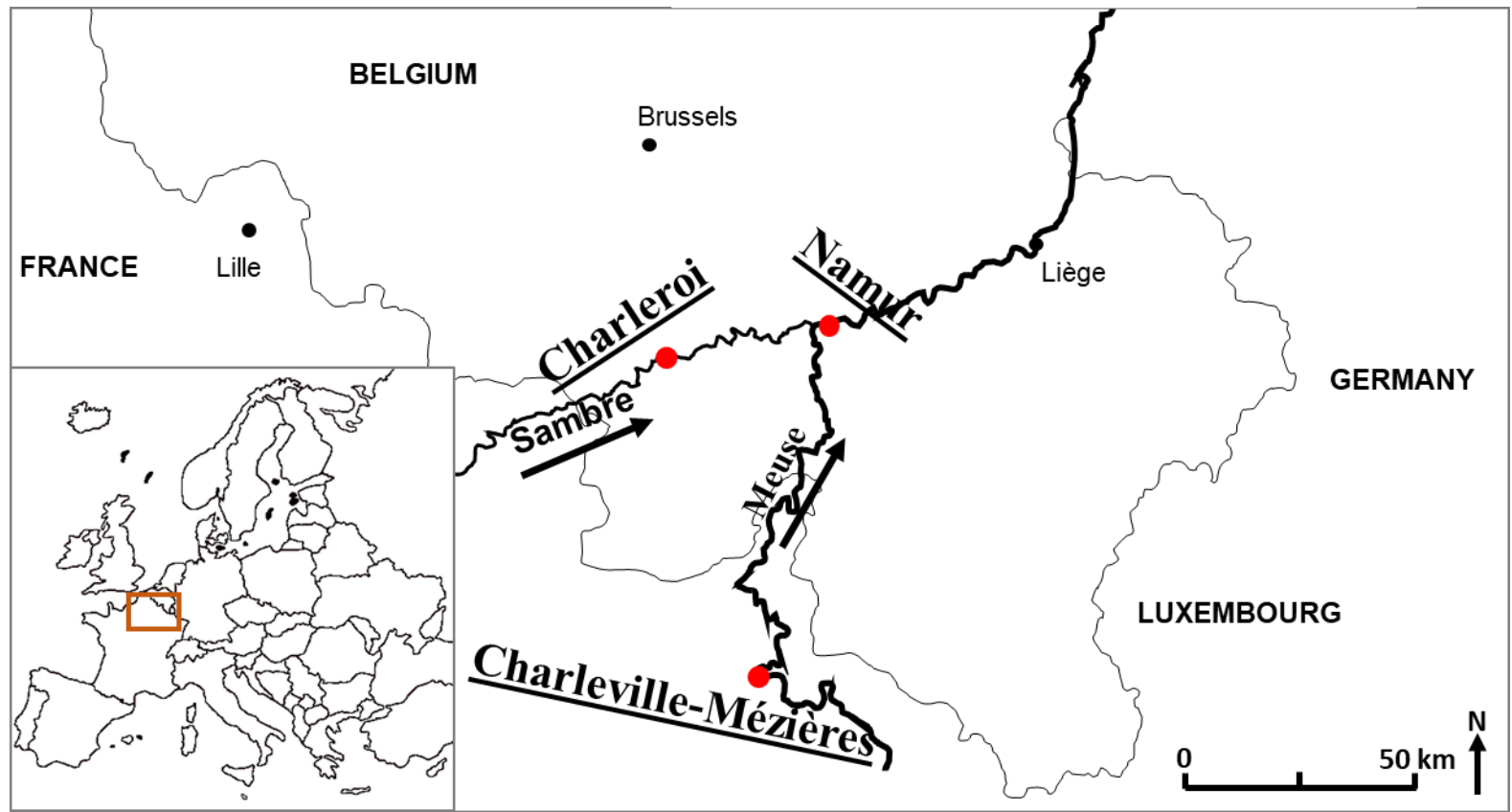


Table 1: GPS coordinates and water physico-chemical parameters (mean \pm S.D.) of each experimental site.

\begin{tabular}{|c|c|c|c|c|c|c|c|}
\hline \multirow[b]{2}{*}{ Station } & \multirow[b]{2}{*}{ Site } & \multirow[b]{2}{*}{ GPS coordinates } & \multirow{2}{*}{$\begin{array}{c}\text { Distance } \\
\text { from } \\
\text { downstream } \\
\text { site (m) }\end{array}$} & \multicolumn{4}{|c|}{ Water parameters } \\
\hline & & & & $\begin{array}{c}\text { Temperature } \\
\left({ }^{\circ} \mathbf{C}\right)\end{array}$ & $\begin{array}{c}\text { Dissolved } \\
\text { Oxygen }(\mathrm{mg} / \mathrm{L})\end{array}$ & pH & $\begin{array}{c}\text { Conductivity } \\
(\boldsymbol{\mu S} / \mathbf{c m})\end{array}$ \\
\hline \multirow{2}{*}{$\begin{array}{c}\text { Charleville- } \\
\text { Mézières } \\
\text { (CM) }\end{array}$} & Upstream & 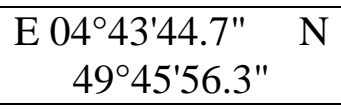 & 100 & $11 \pm 3$ & $10 \pm 0$ & $8 \pm 0$ & $597 \pm 13$ \\
\hline & Downstream & $\begin{array}{c}\text { E 0 } 4^{\circ} 43^{\prime} 46.9^{\prime \prime} \\
49^{\circ} 45^{\prime} 59.6^{\prime \prime}\end{array}$ & - & $11 \pm 3$ & $10 \pm 0$ & $8 \pm 0$ & $598 \pm 13$ \\
\hline \multirow{2}{*}{$\begin{array}{l}\text { Charleroi } \\
\qquad(\mathrm{Cr})\end{array}$} & Upstream & 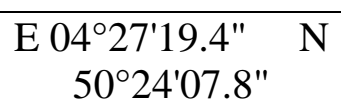 & 2,000 & $12 \pm 3$ & $8 \pm 1$ & $8 \pm 0$ & $673 \pm 16$ \\
\hline & Downstream & $\begin{array}{c}\mathrm{E} 04^{\circ} 29^{\prime} 27.4^{\prime \prime} \\
50^{\circ} 23^{\prime} 44.7^{\prime \prime}\end{array}$ & - & $12 \pm 3$ & $6 \pm 2$ & $8 \pm 0$ & $1025 \pm 172$ \\
\hline \multirow{3}{*}{$\begin{array}{l}\text { Namur } \\
\text { (Nam) }\end{array}$} & Upstream1 & $\begin{array}{c}\text { E 0451'38.8" } \\
50^{\circ} 26^{\prime} 38.4^{\prime \prime}\end{array}$ & 8,000 & $13 \pm 4$ & $11 \pm 0$ & $8 \pm 0$ & $537 \pm 39$ \\
\hline & Upstream2 & 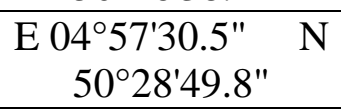 & 40 & $13 \pm 4$ & $10 \pm 0$ & $8 \pm 0$ & $741 \pm 147$ \\
\hline & Downstream & $\begin{array}{cc}E 04^{\circ} 57^{\prime} 32.9^{\prime \prime} & \mathrm{N} \\
50^{\circ} 28^{\prime} 49.4^{\prime \prime} & \\
\end{array}$ & - & $13 \pm 3$ & $10 \pm 1$ & $8 \pm 0$ & $763 \pm 141$ \\
\hline
\end{tabular}




\subsection{Sample preparation}

165

166

167

168

169

170

171

172

173

174

175

176

177

178

179

180

181

182

183

184

185

186

To minimize the effects of field dissection on their metabolome as much as possible (Watanabe et al. 2015), a group of mussels ( $\mathrm{n}=10$ per site) was directly frozen in liquid nitrogen on-site, and then stored at $-80{ }^{\circ} \mathrm{C}$ until metabolomic processing. The remaining mussels were transferred to the laboratory in aerated water recovered from each site and then acclimated for $12 \mathrm{~h}$ before dissection. Then, they were weighed to the nearest $1 \mathrm{mg}$ with a Sartorius ED224S balance, measured with vernier calipers to the nearest $0.1 \mathrm{~mm}$ (length $\mathrm{x}$ width $\mathrm{x}$ height), and dissected from their shells, and processed as follows: for the core biomarkers, soft samples were weighed and stored at $-80^{\circ} \mathrm{C}$ as pools of three digestive glands ( $\mathrm{n}=9$ pools per site) for digestive enzyme activities, and pools of three whole organisms ( $n=9$ pools per site) for the other energy biomarkers. For bioaccumulation assays, pools of $2 \mathrm{~g}$ of whole organisms were prepared: three pools were directly frozen at $-80^{\circ} \mathrm{C}$ for inorganic bioaccumulation assays, and three other pools were frozen in liquid nitrogen, lyophilized and then stored at $-80^{\circ} \mathrm{C}$ for organic bioaccumulation assays.

Water samples were collected at least 2 times per month and per site, at the beginning and at the end of the month, in amber 0.5 -L glass bottles, and stabilized by adding sodium thiosulfate $\left(2.5 \mathrm{~mL}\right.$ of $\mathrm{Na}_{2} \mathrm{~S}_{2} \mathrm{O}_{3} .5 \mathrm{H}_{2} \mathrm{O}$ at $\left.1.9 \mathrm{~g} / \mathrm{L}\right)$. The samples were then stored at $5 \pm 3{ }^{\circ} \mathrm{C}$ in the dark and extracted within 48 hours of sampling.

\subsection{Chemical analyses}

\subsubsection{Water analysis}

Water was filtered, and 0.25-L samples were processed after adjusting the $\mathrm{pH}$ at $7 \pm 0.2$.

A solid-phase extraction was performed with an automatic extractor (Smartprep ${ }^{\mathrm{TM}}$, Horizon Technologies). The samples were eluted with acetonitrile (LC-MS/MS grade), and analyzed 
with an Agilent 1290 liquid chromatograph coupled to an Agilent 6490 QQQ tandem mass spectrometer. Extraction, quantification methods and the list of the targeted chemical compounds are detailed in Supplementary Data (c.f. S1.1, and tables S1, S2).

\subsubsection{Mussel bioaccumulation analysis}

For organic compounds (Polychlorinated biphenyls "PCBs", Polycyclic aromatic hydrocarbons "PAHs", Polybrominated diphenyl ethers "PBDEs"), freeze-dried homogenized mussels were treated with a modified QuEChERS extraction approach (Kalachova et al. 2011), and analyzed by atmospheric pressure gas chromatography/spectrometry (APGC), using an Agilent 7890B GC system (Agilent, Palo Alto, CA, USA). For heavy metals (Cadmium "Cd", Copper “Cu”, Nickel “Ni”, and Zinc “Zn”), soft tissues were mineralized with Suprapur® nitric acid for $24 \mathrm{~h}$ at $80{ }^{\circ} \mathrm{C}$. The resulting acidic solutions were adjusted to $10 \mathrm{~mL}$ with ultrapure water, and samples were analyzed using an inductively coupled plasma optical emission spectrometer (ICP-AOS, Thermo Scientific iCAP 6300 DUO). Results were reported in $\mu \mathrm{g} / \mathrm{kg}$ wet weight for organic compounds, and $\mu \mathrm{g} / \mathrm{g}$ wet weight for heavy metals.

\subsection{Core biomarker analyses}

Several energy biomarkers were addressed. Firstly, digestive enzyme (amylase, acid phosphatase (ACP), lipase and lactate dehydrogenase (LDH)) activities were assayed on the cytosolic fraction of digestive gland samples, after 30 minutes' centrifugation (c.f. S1.2, for extraction), using Thermo-Scientific Gallery ready-to-use reagents on an automated photometric analyzer (Gallery ${ }^{\mathrm{TM}}$, Thermo Fisher Scientific Oy) following the manufacturer's protocols. Each enzyme activity was expressed as U/g of protein.

Energy consumption (Ec) was evaluated by measuring the activity of the electron transport system (ETS) in the supernatant after $10 \mathrm{~min}$ of centrifugation at 3,000g (c.f. S1.2.), 
according to De Coen and Janssen (1997a). ETS activity was then transformed into energy

211 equivalents using an average oxyenthalpic equivalent of $480 \mathrm{~kJ} / \mathrm{mol} \mathrm{O}_{2}$, and results were expressed as $\mathrm{mJ} / \mathrm{mg}$ wet $\mathrm{wt} / \mathrm{h}$ (De Coen and Janssen, 1997a).

214 parameters recorded from individuals that were used for metabolomics: [CI= Soft tissue dry 215 weight $(\mathrm{g}) /($ length $\mathrm{x}$ width/height $(\mathrm{mm}))]$.

For energy reserves, protein contents were measured after extraction according to standard. Lipids and carbohydrates were measured according to protocols adapted from Plaistow et al. (2003), using olive oil (Sigma-Aldrich Chemicals, France) and glucose solutions (Sigma-Aldrich Chemicals, France) as standards. The whole-body energy reserves budget (Ea) was calculated by summing the energetic values of the different reserves $\left[\mathrm{Ea}=\sum\right.$ (total lipids, carbohydrates and proteins) (mJ/mg wet wt/h)], using an enthalpy of combustion of $17.5 \mathrm{~kJ} / \mathrm{g}$ for carbohydrates, $39.5 \mathrm{~kJ} / \mathrm{g}$ for lipids and $24 \mathrm{~kJ} / \mathrm{g}$ for proteins.

Finally, an integrative biomarker (CEA: cellular energy allocation) was calculated after determining Ea and Ec, according to the following formula: [CEA = Ea/Ec] (Verslycke et al., 2004).

\section{5. ${ }^{1}$ H-NMR metabolomics}

Frozen mussels were measured with vernier calipers to nearest $1 \mathrm{~mm}$ (length $\mathrm{x}$ width $\mathrm{x}$ height), dissected on ice, and soft tissues were removed from the shell using a pre-cleaned surgical scalpel. Then, whole organisms were individually frozen in 2-mL Eppendorf tubes at $-80{ }^{\circ} \mathrm{C}$. Extraction was performed on $10 \mathrm{mg}$ of ground whole organism lyophilizate, using the 
tissue extracts were resuspended in $600 \mu \mathrm{L}$ of $0.1 \mathrm{M}$ deuterated phosphate buffer (pH 7) (c.f.

S1.4.), vortexed and then transferred into standard 5-mm NMR tubes (Norell ${ }^{\circledR}$ ) for analysis

with a Bruker AV III 600 NMR spectrometer (Bruker, Wissembourg, France) at the Institute of Molecular Chemistry of Reims (ICMR, Champagne Ardenne University, France). The detailed acquisition process is reported in Supplementary Data S1.4.

Prior to statistical processing, the spectra were pre-processed by NMRProcFlow, an open-source software program developed by Jacob et al. (2017) and dedicated to metabolomics, as described in Supplementary Data S2. Spectra were annotated following Prud'homme et al. (2020) and based on the combination of several 1D and 2D approaches to assign each metabolite as confidently as possible (c.f. S1.4.).

\subsection{Statistical analyses}

\subsubsection{Biological and chemical parameters}

Statistical analyses of all biomarkers and chemical analyses (bioaccumulation and water chemical results) were performed using R software (v3.3.1), and were considered significant when $\mathrm{p}<0.05$. One-way ANOVA and a Tukey HSD post-hoc test were performed after testing normality (Shapiro test) and homogeneity (Levene test). When normality or homoscedasticity were not met, data were transformed using a log or square-root method. A nonparametric test (Kruskal-Wallis) was used, followed by a non-parametric post-hoc test (Dunn's test with Bonferroni adjustment) for bioaccumulation and water chemistry results, and for biological parameters when data transformation was useless. Additionally, a multivariate statistical analysis (unsupervised PCA) was performed for energy biomarkers using Biostatflow platform (v.2.9.2; http://biostatflow.org). Statistical tests were performed on upstream results, using station (CM-Upstream, Cr-Upstream and Nam-Upstream1) as a factor to test the interstation effect. For bioaccumulation and water chemistry results, given the low number of 
replicates and the absence of significant differences between upstream and downstream

258 locations in the different stations for most chemicals, interstation effect was evaluated on the merged upstream and downstream data from each station. Intrastation effect was evaluated independently for each station using site (upstream/downstream) as a factor for all parameters.

\subsubsection{Metabolomics data}

NMRProcFlow pre-processing generated 418 buckets from 0.91 to $10 \mathrm{ppm}$ after zeroing the water signal and blank contaminant peaks. The generated data matrix was imported into Biostatflow platform (v.2.9.2; http://biostatflow.org, a web application developed for the statistical analyses of "OMICS" Data, using R scripts). Hence, all multivariate statistical analyses (unsupervised principal component analysis "PCA" and supervised linear kernelorthogonal projection to latent structures "K-OPLS") were performed on this platform. Then, a univariate test (non-parametric Kruskal-Wallis test) was performed to check for significant abundance differences of the identified metabolites between the experimental groups (as described in Supplementary Data S1.5.). Interstation effect was tested on CM-Upstream, CrUpstream and Nam-Upstream1, and intrastation effect was tested on each station separately using site (upstream/downstream) as a factor. For the univariate and multivariate statistical

273 tests, the dependent variables were the generated buckets.

\section{Results and discussion}

\subsection{Water quality and mussel exposure to field contamination}

The water physico-chemical parameters of the sites (Table 1) fell within the ecological requirements of the species found in the literature (McMahon, 1996; Navarro et al., 2006), and no mortality was observed at the end of the experiment. Although the oxygen concentration in growth-inhibiting concentration (2 mg/L) reported for D. polymorpha (Navarro et al., 2006). 
Water chemical analysis and mussel bioaccumulation assay results are reported and

282 discussed in detail in Supplementary Data S2. Briefly, mussels were exposed to different 283 contaminants, more so in the Sambre than in the Meuse. Compared to other European rivers,

the water quality of the Meuse watershed has improved over the last decades, with the 285 implementation of WWTPs and the application of water policies (van Vliet and Zwolsman, 2008). However, a spatial dichotomy still remains observable, with a less polluted upstream

287 portion of the river (French Meuse) and a deteriorated water quality in the downstream portion 288 beyond the Belgian border. This deteriorated quality of the Meuse is admittedly due to the 289 inflow of the Sambre which remains greatly polluted compared to the Meuse (van Vliet and 290 Zwolsman, 2008). Our results support this hypothesis.

\subsection{Energy metabolism biomarkers}

Our study addressed eight biomarkers of the energy metabolism in zebra mussels: ETS, digestive enzymes activities (ACP, lipase, LDH, amylase), energy reserves, CEA and condition 294 index.

When addressing the interstation effects, we compared CM-Upstream, Cr-Upstream and Nam-Upstream1 data. Based on bioaccumulation and water chemistry results (c.f. S2.), water quality in Nam-Upstream2 tend to be impacted (though not significantly) by the Sambre river inflow, so we chose Nam-Upstream1 (located $5 \mathrm{~km}$ upstream of the Sambre-Meuse confluence) rather than Nam-Upstream2 for further analyses. Figure S1 shows graphical representations of PCA and KOPLS results according to stations and energy metabolism parameters. For PCA 301 results, the first two principal components (PC1 and PC2) explained $6459.9 \%$ of total variance 302 (figure S1 A and B). Namur individuals seem to have higher CEA and lipase activity. The other 303 energy parameters (except CI) seemed to be higher in Charleville-Mézières and Charleroi 
observed between groups, and the model was valid after permutation test $(\mathrm{p}=0.003)$. Figure 2 represents univariate statistical results of each biomarker. For condition index, amylase activity and CEA no significant differences were recorded. ACP, lipase and LDH activities, total reserves and ETS showed significant differences $(p<0.05)$ between Charleroi mussels and mussels from the other stations. Charleroi mussels notably displayed 1.2-fold higher energy reserves and a higher energy consumption rate (ETS activity 1.3 to 1.4-fold higher) compared 311 to Charleville-Mézières and Namur mussels. In Namur individuals, ACP and LDH activities were 1.3 to 1.6 fold lower and lipase activity was 1.1 fold higher, compared to CharlevilleMézières (One-way ANOVA, $\mathrm{df}=2, p<0.01$ ), which is in accordance with PCA results. and downstream of the three stations (Figure S2), while the univariate statistical test showed one in Charleville-Mézières and Namur but not in Charleroi (Figure 2). ACP and LDH activities were higher in Namur station (1.14 and 1.3-fold, respectively, Kruskal-Wallis, $\mathrm{df}=2, p<0.03$ ), downstream of the discharge of the Sambre and Namur WWTP effluents into the Meuse (NamUpstream1 vs. Nam-downstream). However, although LDH activity was 1.3-fold lower in Nam-Upstream1 mussels than in Nam-Uptream2 mussels (Kruskal-Wallis, $\mathrm{df}=2, p=0.01$ ), ACP 321 activity did not differ, suggesting that only LDH activity was affected by the Sambre discharge 322 into the Meuse. In Charleville-Mézières, mussels caged downstream of the WWTP had higher 323 energy reserves (1.15-fold, Kruskal-Wallis, $\mathrm{df}=1, p=0.02)$ and displayed higher ETS activity 324 (1.37-fold, One way ANOVA, $\mathrm{df}=1, p<0.01)$ than those caged upstream.

Digestive enzyme activities (LDH, lipase and ACP) were dependent on station and site (in Namur, except for lipase). Energy acquisition from ingested food is ensured in the first place 327 by enzymatic digestion. Digestive enzymes are admittedly potential biomarkers in 328 ecotoxicology to characterize the chemical contamination of aquatic environments (Dedourge- 
Geffard et al., 2009; Hani et al., 2018; Palais et al., 2012; Wang et al., 2015). Decreased

330 digestive enzyme activity has indeed been reported in various aquatic organisms (Chen et al.,

331 2002; De Coen and Janssen, 1997b; Hani et al., 2018), although some authors reported no effect

332 (Bourgeault et al., 2010). Our study reveals a high level of chemical contamination both in

333 water and mussels in Charleroi station compared to the other stations (c.f. S2.). However,

334 Charleroi mussels displayed higher, lower or similar digestive enzyme activities compared to

335 mussels caged in the other stations. Besides, Nam-Downstream exhibited higher contamination

336 by pharmaceuticals and iodinated contrast media (Table S4), which potentially caused the

337 observed increase in ACP and LDH activities. Overall, our observations make it difficult to

338 generalize links between digestive enzyme activity and site chemical pressures.

Charleroi mussels also displayed significantly higher ETS activity associated with 340 greater energy reserves than the other stations. ETS activity is usually used to measure 341 metabolic activity in the form of potential oxygen consumption, and has been proposed as an

342 indicator of aquatic organism metabolism in situ (Cammen et al., 1990; Fanslow et al., 2001).

343 We conducted our study in fall, when zebra mussels are at sexual rest and replenish their energy

344 reserves (Palais et al., 2012). Our results suggest that Charleroi mussels had sufficient energy

345 intake to restore their energy reserves, in parallel with high energy consumption, although the

346 water in the area was the most contaminated (c.f. S2.). The higher ETS activity associated with

347 higher energy reserves was also observed in CM-Downstream compared to CM-Upstream, 348 although the effluents of this station did not seem to influence chemical water quality or the 349 contamination state of mussels (c.f. S2.).

Energy is the most determining biological parameter involved in all the physiological

351 processes of living beings; hence, energy metabolism parameters can be useful biomarkers of 352 the effects of chemicals on different aquatic organisms (De Coen et al., 2000; Dedourge- 
353 Geffard et al., 2012; Hani et al., 2018; Palais et al., 2012). In our study we addressed only 8

354 biomarkers related to energy metabolism, and the multi- and univariate statistical analysis

355 results evidenced an emerging trend that potentially differentiated the different experimental

356 groups. However, highlighting a clear response pattern associated with chemical contamination

357 levels remains difficult. This suggests that the response of energy-related biomarkers could not

358 only be linked to chemical contamination but also to other environmental parameters

359 representing confounding factors in in situ studies, even if we proceeded with a methodology

360 which aimed to limit the influence of these factors. One solution could be to address many

361 parameters at the same time and then to identify a priori a group of potential inter-related

362 biomarkers whose impact could draw a response pattern clearly reflecting the health status of

363 organisms and the chemical state of their environment. This is why a global metabolomics

364 approach was applied to identify potential biomarkers and better understand mussel responses

365 to water quality. 

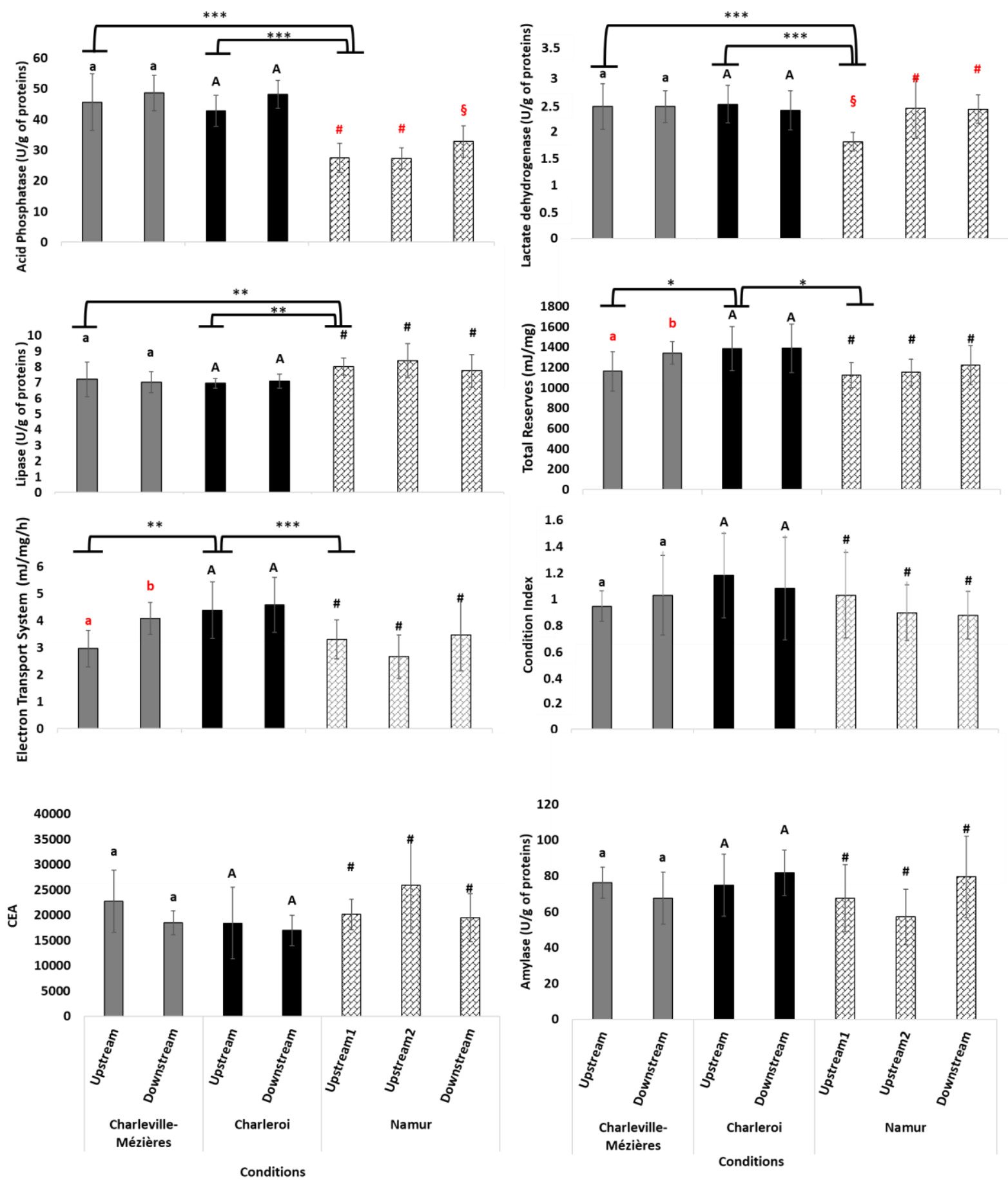

370 Figure 2: Energy metabolism biomarkers after 2 months of mussels caging upstream and

371 downstream of three wastewater treatment stations (Charleroi, Charleville-Mézières,

372 Namur). Results are presented as mean \pm S.D. For the same station, different letters indicate significant

373 differences between upstream and downstream samples (Intrastation effects, $p<0.05$ ). Asterisks indicate significant interstation

374 differences (Charleroi vs. Charleville-Mézières vs. Namur; ${ }^{*} p<0.05 ;{ }^{* *} p<0.01 ;{ }^{* *} p<0.001$ ). 


\section{3. $\quad{ }^{1}$ H-NMR metabolomics}

Among the metabolites identified in Prud'homme et al. (2020), we detected and assigned 28 compounds, including 11 proteinogenic amino acids (alanine, aspartate, glutamate, glutamine, glycine, isoleucine, leucine, lysine, phenylalanine, tyrosine, valine), 5 amine compounds (betaine, cadaverine, choline, putrescine, trimethylamine), 3 nucleotides (ATP, ADP, AMP), 3 nucleosides (adenosine, uridine, inosine), 2 organic acids (succinate, lactate), 2 carbohydrates (glucose, maltose), 1 alkaloid (nicotinic acid), and 1 coenzyme (NAD).

To visualize the interstation effects on the zebra mussel metabolome, we compared the same data as we did for biomarkers, i.e., CM-Upstream, Cr-Upstream and Nam-Upstream1. A non-supervised PCA was first performed. The score plot (Figure 3A) highlighted a clear separation between the three stations (especially for Charleroi), in line with energy biomarker results. The first two dimensions of the PCA expressed about $89 \%$ of the total variance, mostly explained by PC1 $(83 \%, p<0.01)$. The metabolomic profiles clearly differed among stations, suggesting that the mussels' metabolic state was influenced by the local environmental conditions. A subsequent supervised approach was used to identify metabolites with a higher contribution to this interstation discrimination. The K-OPLS model confirmed the differences in metabolomic profiles among stations (Figure 3B). Our model was highly predictive (Q2=77 $\%$ ), and explained $80 \%$ of interstation variability, and the permutation test confirmed its validity $(p=0.02)$. In K-OPLS, an important feature is the variable importance in projection (VIP) scores. High VIP-score variables strongly contribute to the model construction. In total, 80 variables (including assigned and non-assigned buckets) with a VIP> 1.2 were observed; three of them were identified as being lactate (VIP=1.32), glycine (VIP=1.27) and maltose $(\mathrm{VIP}=1.25)$. The others were mainly located in the $3-4 \mathrm{ppm}$ region of the spectrum, corresponding to a highly complex region where resonance of carbohydrates, amino acids and 
nucleotides overlapped, making their identification difficult, as explained by Prud'homme et

400 al. (2020). Then, we used univariate analysis (Kruskal-Wallis nonparametric test) to verify if 401 metabolite abundance differed significantly among mussels from the different stations. Lactate was more abundant in mussels from Charleroi, followed by Charleville-Mézières and then Namur (Kruskal-Wallis, $\mathrm{df}=2, p<0.01$, Figure S3 A). A significant difference was also observed for glycine (Kruskal-Wallis, $\mathrm{df}=2, p=0.01$ ) and maltose (Kruskal-Wallis, $\mathrm{df}=2, p=0.04$ ), in line with lactate (higher in Charleroi mussels than in the other groups) (Figure S3 B and C, respectively). Those three metabolite abundances seemed to be particularly impacted by station-specific environmental conditions. showed no significant separations between upstream and downstream in Charleroi and Charleville-Mézières. However, Nam-Downstream mussels were slightly distinguished from Nam-Upstream1 and Nam-Upstream2 mussels, with variability mostly explained by PC1 (85 $\%, p=0.02$ ). Supervised K-OPLS was then applied to search for a significant separation between the upstream and downstream sites of each station (Figure 4 B, D, F). K-OPLS showed a great 414 upstream vs. downstream separation in Namur and Charleville-Mézières, but not in Charleroi. 415 The absence of effects in Charleroi could be explained by the high contamination level of the 416 Sambre both upstream and downstream of the WWTP. Interestingly, although Charleroi cages 417 were $2 \mathrm{~km}$ apart (Table 1), the mussels' metabolome was highly modulated compared to the 418 other stations, and in the same way upstream and downstream. The generated statistical models 419 were valid $(p<0.05)$, predictive $(\mathrm{Q} 2=56 \%$ and $46 \%)$, and explained $33 \%$ and $82 \%$ of 420 variability in Charleville-Mézières (Figure 4B) and Namur (Figure 4F), respectively. K-OPLS 421 satisfactorily explained and predicted metabolome variation. This variation was explained by 42249 and 60 variables (including assigned and non-assigned buckets) with a VIP score $>1.20$ for 423 Charleville-Mézières and Namur, respectively. Among these, 8 metabolites were identified to 
424 be glutamine (VIP=2.07), putrescine (VIP=1.71), ADP/ATP (VIP=1.53), trimethylamine 425 (VIP=1.51), cadaverine (VIP=1.40), AMP (VIP=1.32), lysine (VIP=1.22) and UDP/UTP 426 (VIP=1.20) in Charleville-Mézières sites. Kruskal-Wallis tests showed no significant difference 427 between CM-Upstream and CM-Downstream $(p>0.05)$ for these metabolites; moreover, 428 unsupervised multivariate PCA failed to clearly discriminate upstream mussels from 429 downstream mussels in Charleville-Mézières, suggesting that intrastation changes identified by 430 supervised K-OPLS (which explained only $33 \%$ of data variability) may have been masked by 431 high interindividual variability, leading to inconclusive univariate approaches. High 432 interindividual metabolome variability could be due to a gender effect, as previously evidenced 433 in bivalves (Hines et al., 2007). Our study was conducted when zebra mussels were at sexual 434 rest, a period where gender identification is difficult since the gonad are not differentiated. In 435 Namur, only 2 metabolites were identified: glutamate (VIP=1.29) and lactate (VIP=1.24). Both of them were lower in Nam-Upstream1 than in the other two sites, but only significantly 437 (Dunn's test, $p<0.05$ ) when compared to Nam-Downstream (Figure S4). Therefore, lactate was 438 higher when the pollution was higher, as in Nam-Downstream and Charleroi compared to the 439 other stations. Other variables (non-identified buckets) highly contributed to site separation but 440 were mainly located in the 3-4 ppm region of the NMR spectrum and could not be associated 441 with a specific metabolite.

443 the other stations, and the upstream/downstream of Namur and Charleville-Mézières stations. 444 In our study, metabolomics was more efficient than the chosen biomarkers, perhaps because 445 with the classical approach we addressed only 8 biomarkers, whereas with metabolomics we 446 addressed several parameters at the same time without a priori, which broadens the potential to 447 identify a clear response pattern related to our experimental conditions. Metabolomics probably 448 identified other markers more informative about the effect of water quality than the 
conventional biomarkers addressed in this study. This underlines the potential and complementarity of the two approaches in the biomonitoring of aquatic environments. to assess the health status of organisms by measuring small metabolites involved in different aspects of physiological processes (Brew et al., 2020; Nguyen and Alfaro, 2020). The production and levels of these metabolites can be modulated by physiological and/or environmental factors (Campillo et al., 2019; Cappello et al., 2013; Dumas et al., 2020; Lin et al., 2006). We identified 4 metabolites (glycine, glutamate, maltose and lactate) involved in different metabolic pathways and significantly impacted by the experimental conditions. As all mussels originated from the same population, metabolite modulation is attributable to changes in environmental conditions in each station and site.

Lactate (2-hydroxypropanoate), is a hydroxycarboxylic acid, and one of the endproducts of anaerobic pyruvate metabolism (De Zwaan and Dando, 1984). The significant increase in lactate in Charleroi mussels compared to the other stations (interstation effect) and in those of Nam-downstream compared to the other Namur sites (intrastation effect) suggests a 464 disturbance of the mussels' energy metabolism inducing higher anaerobic energy production. This can presumably be explained by pollution-induced closing of mussels valves, which obviously stimulated the anaerobic metabolism of our experimental animals. Closure of valves 467 is one of the behavioral adaptations of mussels to limits the harmful effects of pollutants which 468 leads to a switch to anaerobic pathways (Isani et al., 1995; Madon et al., 1998; Rist et al., 2016; 469 Slooff et al., 1983; Wright et al., 2013). In green mussels (Perna viridis), higher lactate was 470 observed after one and two weeks' exposure to cadmium, copper and their combination, and 471 the authors supposed that the mussels' energy metabolism was impacted by this exposure (Wu 472 and Wang, 2010, 2011). Lactate production has been reported as an energy modulation strategy 
473 in aquatic organisms under different stress conditions. For example, in Perna canaliculus

474 mussels, lactate was one of 38 identified metabolites detected $24 \mathrm{~h}$ post injection with Vibrio $475 s p$. Lactate accumulation suggested that Vibrio sp. impacted the mussels' energy metabolism 476 by limiting pyruvate conversion into citrate (Thao V. Nguyen et al., 2018). In olive flounder 477 fish (Paralichthys olivaceus), lactate was one of the metabolites identified by Kim et al. (2020) 478 after thermal stress. Additionally, when NMR metabolomics was used to evaluate the freshness 479 of commercial mussels (Mytilus galloprovincialis), lactate was one of the metabolites that 480 discriminated fresh mussels from stored ones (Aru et al., 2016). Hence, lactate is a potential 481 biomarker of the health status of zebra mussels in ecotoxicological studies. Lactate is produced 482 by a reversible redox reaction catalyzed by the enzyme lactate dehydrogenase (LDH) (Adeva483 Andany et al., 2014; Le et al., 2010). The significant decrease in lactate in Nam-Upstream1 and 484 increase in Charleroi were corroborated by our LDH assay results, which revealed a low activity 485 in Nam-Upstream1 compared to the other stations and other Namur sites (Figure 2). This 486 interesting result supports the complementary aspect of metabolomics, which identified new 487 parameters likely to complete the set of energy biomarkers currently used to evaluate the health 488 status of aquatic organisms.

Glycine and glutamate are free amino acids that were higher in Charleroi mussels 490 (compared to the other stations) and in Nam-Upstream2 and Nam-Downstream mussels 491 (compared to Nam-Upstream1). This could suggest changes in zebra mussel osmotic regulation 492 and anaerobic energy metabolism under our experimental conditions. In bivalves, free amino 493 acids are important in osmoregulation and considered as end-products, substrates or 494 intermediates of anaerobic energy metabolism (Zurburg and De Zwaan, 1981). Zebra mussels 495 are hyperosmotic regulators (Dietz et al., 1996), and hyperosmotic regulation in mollusks 496 appears to depend on the synthesis of amino acids involving anaerobic pathways (Zurburg and 497 De Zwaan, 1981). Four anaerobic pathways are known in invertebrates: the aspartate-succinate, 
498 glucose-succinate, opine, and lactate pathways (Lee and Lee, 2011). In bivalves, the anaerobic metabolism is dominated by the opine pathway involving opine dehydrogenases (e.g., strombine dehydrogenase (SDH), octopine dehydrogenase (ODH)), whereas in vertebrates the

501 lactate pathway (involving LDH) is the main route for anaerobic energy production (De Zwaan 502 and Dando, 1984; Lee and Lee, 2011). Gäde and Zebe (1973) found that ODH played a more 503 important role than LDH in zebra mussels, which supports the predominance of the opine 504 pathway in their anaerobic metabolism. We observed glycine accumulation in Charleroi (the 505 most contaminated station) mussels. Glycine is known to be catalyzed anaerobically (with pyruvate and NADH) by SDH to produce energy (one of the opine pathways) (Lee and Lee, 2011). Glycine and lactate accumulation could suggest that under our experimental conditions, 508 the mussels' opine pathway (represented by SDH activity) was inhibited and anaerobic energy 509 production was ensured by the lactate pathway. This corroborates the energy metabolism disturbance hypothesis. This also supports the relevance of lactate as a potential biomarker in zebra mussels. In addition, glycine and glutamate with cysteine are also involved in the

512 glutathione metabolic pathway (production of glutathione "GSH") (Thao V Nguyen et al., 513 2018). GSH is an important cellular thiol, involved in different biological processes such as the 514 protection of cells against the toxic effects of a variety of endogenous and exogenous 515 compounds, including oxygen reactive species and pollutants (antioxidant role) (Canesi et al., 516 1999). The accumulation of glycine and glutamate could represent a signature of a possible 517 oxidative stress due to the disruption of the anaerobic metabolism of zebra mussels under our 518 experimental conditions. 
${ }^{1} \mathrm{H}-\mathrm{NMR}$ metabolomics emerges as a strong and sensitive approach that could be used

523 to assess the global health status of zebra mussels in biomonitoring of aquatic environments.

524 Using this global approach, we identified different metabolic profiles among mussels from the

525

526 mussels.

same provenance and the same population, caged no more than $100 \mathrm{~m}$ apart, upstream and downstream of two WWTPS (Namur and Charleville-Mézières). ${ }^{1} \mathrm{H}-\mathrm{NMR}$ metabolomic results were consistent with the contamination states of the different stations/sites, and allowed us to identify 4 metabolites (lactate, maltose, glutamate and glycine). One of them (lactate) is a potential future biomarker of the health status of zebra mussels in ecotoxicological studies. Interestingly, one of the "classical approach" energy biomarkers - LDH - was modulated together with its substrate - lactate - identified by the metabolomic approach; this underlines the potential of metabolomics, especially if combined with a classical biomarker approach. One advantage of metabolomics is that it focuses on several metabolites at a time, with significant time saving and the possible identification of potential biomarkers targetable individually thereafter. Therefore, we suggest using metabolomics without a priori in the first place to identify metabolites and subsequently evaluate and validate their potential as biomarkers.

The combination of metabolomics and classical biomarkers was already reported in the literature in serval marine organisms including fish and bivalves (Brandão et al., 2015; Caricato et al., 2019; Digilio et al., 2016; Ji et al., 2015), however, to our knowledge this is the first study that combines the use of biomarkers and metabolomics to assess the health status of zebra 542 

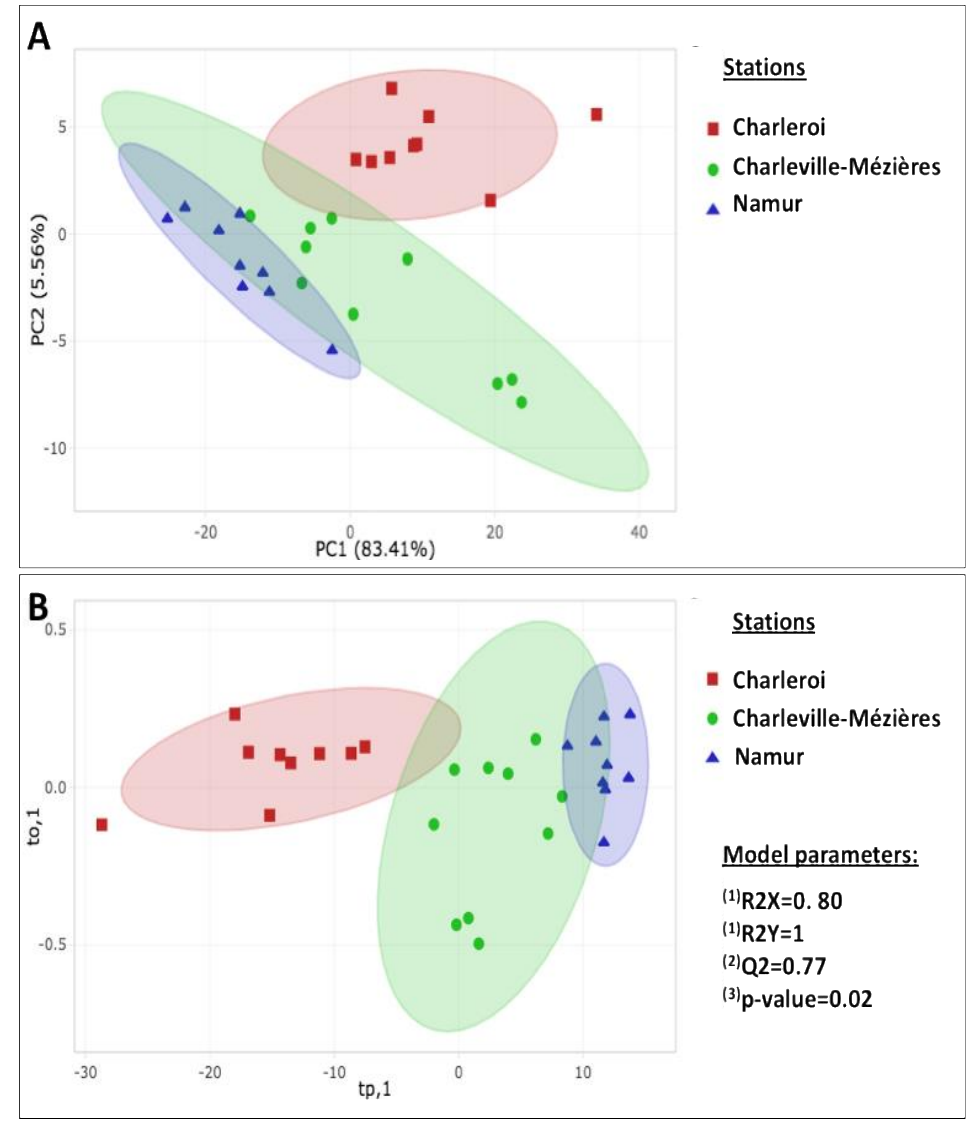

546 Figure 3: PCA score plots (A) and Kernel-Orthogonal Projections to Latent Structures

547 (K-OPLS) model (B) of mussels after 2 months of mussels caging in Charleville-Mézières

548 upstream, Charleroi upstream and Namur upstream 1 (data of interstation effect). Ellipses

549 were drawn with a $95 \%$ confidence interval. In (B), K-OPLS model validation parameters were: (1) R2X and R2Y, which

550 represent the cumulative explained variation for all model components; (2) Q2, the predictive power of the model; and (3) the

$551 p$-value of the permutation test (model valid when $p<0.05$ ).

552

553 

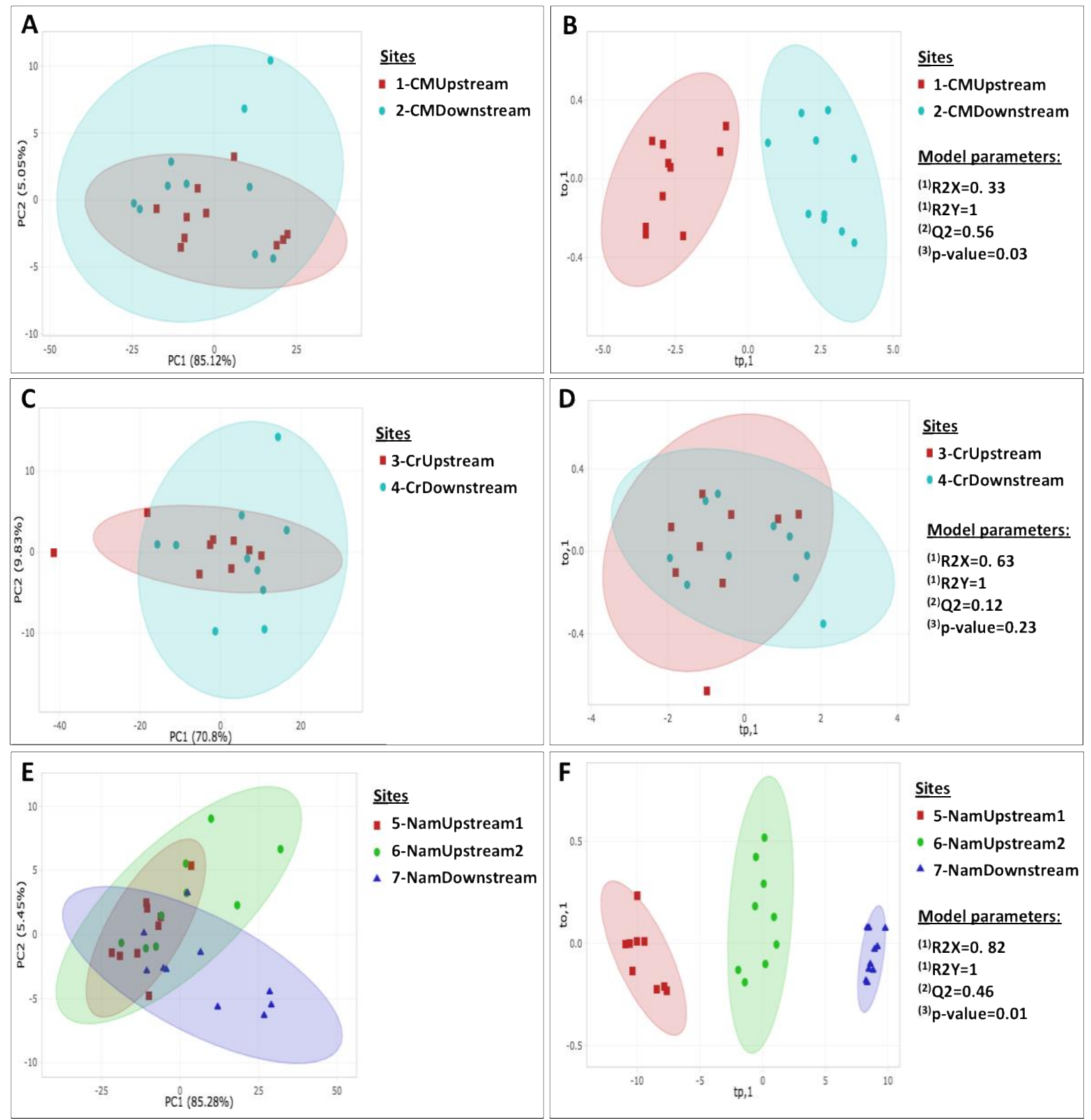

555 Figure 4: PCA score plots (A, C, E) and Kernel-Orthogonal Projections to Latent

556 Structures (K-OPLS) models (B, D, F) showing mussel separation upstream and

557 downstream of Charleville-Mézières (A and B), Charleroi (C and D) and Namur (E and

558 F) stations (data of intrastation effect). Ellipses were drawn with a $95 \%$ confident interval. For (B), (D) and

559 (F), K-OPLS model validation parameters were: (1) R2X and R2Y, which represent the cumulative explained variation for all

560 model components; (2) Q2, the predictive power of the model; and (3) the $p$-value of the permutation test (model valid when $561 p<0.05)$. 


\section{Conclusion}

Our study demonstrates the relevance of ${ }^{1} \mathrm{H}-\mathrm{NMR}$ metabolomics as an efficient

565

Acknowledgments. The authors are grateful to Mrs. Annie BUCHWALTER for editing

approach to assess the health status of zebra mussels in the biomonitoring of aquatic environments. ${ }^{1} \mathrm{H}-\mathrm{NMR}$ metabolomics showed a clear separation of the mussels' profiles according to experimental conditions. This separation was also observed by the classical approach (energy biomarkers), but was not very marked. Our results have nevertheless demonstrated the potential and the corroboration of these two approaches by identifying a metabolite (i.e. lactate) whose abundance was impacted by experimental conditions; in parallel, this impact was observed by the conventional approach, on the enzyme (LDH) which catalyzes the reaction responsible for the production of this metabolite. In addition to lactate, the metabolomic approach made it possible to identify 3 other metabolites (glutamate, maltose and glycine), which were also significantly impacted by the experimental conditions of our study, which suggests that local pollution alters the osmoregulation and energy metabolism of zebra mussels. To our knowledge, our study is the first to combine metabolomics and classical biomarkers to evaluate the effect of field contamination on the health status of zebra mussels.

\section{English language.}


Funding. This work was supported by the European Regional Development Fund (FEDER) in the DIADeM (Development of an Integrated approach for the DiAgnosis of water quality in

Meuse) project of the European program "Interreg France-Wallonie-Vlaanderen".

\section{References}

Adams, S.M., Giesy, J.P., Tremblay, L.A., Eason, C.T., 2001. The use of biomarkers in ecological risk assessment: recommendations from the Christchurch conference on Biomarkers in Ecotoxicology. Biomarkers 6, 1-6. https://doi.org/10.1080/135475001452724

Adeva-Andany, M., López-Ojén, M., Funcasta-Calderón, R., Ameneiros-Rodríguez, E., Donapetry-García, C., Vila-Altesor, M., Rodríguez-Seijas, J., 2014. Comprehensive review on lactate metabolism in human health. Mitochondrion 17, 76-100. https://doi.org/10.1016/j.mito.2014.05.007

Aggelen, G.V., Ankley, G.T., Baldwin, W.S., Bearden, D.W., Benson, W.H., Chipman, J.K., Collette, T.W., Craft, J.A., Denslow, N.D., Embry, M.R., Falciani, F., George, S.G., Helbing, C.C., Hoekstra, P.F., Iguchi, T., Kagami, Y., Katsiadaki, I., Kille, P., Liu, L., Lord, P.G., McIntyre, T., O’Neill, A., Osachoff, H., Perkins, E.J., Santos, E.M., Skirrow, R.C., Snape, J.R., Tyler, C.R., Versteeg, D., Viant, M.R., Volz, D.C., Williams, T.D., Yu, L., 2010. Integrating Omic Technologies into Aquatic Ecological Risk Assessment and Environmental Monitoring: Hurdles, Achievements, and Future Outlook. Environmental Health Perspectives 118, 1. https://doi.org/10.1289/ehp.0900985

Amiard-Triquet, C., Amiard, J.-C., Rainbow, P.S., 2012. Ecological biomarkers: indicators of ecotoxicological effects. CRC Press.

Arrighetti, F., Landro, S.M., Lambre, M.E., Penchaszadeh, P.E., Teso, V., 2019. Multiplebiomarker approach in the assessment of the health status of a novel sentinel mussel Brachidontes rodriguezii in a harbor area. Marine Pollution Bulletin 140, 451-461. https://doi.org/10.1016/j.marpolbul.2019.02.002

Aru, V., Pisano, M.B., Savorani, F., Engelsen, S.B., Cosentino, S., Cesare Marincola, F., 2016. Metabolomics analysis of shucked mussels' freshness. Food Chemistry 205, 58-65. https://doi.org/10.1016/j.foodchem.2016.02.152

Benito, D., Ahvo, A., Nuutinen, J., Bilbao, D., Saenz, J., Etxebarria, N., Lekube, X., Izagirre, U., Lehtonen, K.K., Marigómez, I., Zaldibar, B., Soto, M., 2019. Influence of season-depending ecological variables on biomarker baseline levels in mussels (Mytilus trossulus) from two Baltic Sea subregions. Science of The Total Environment 689, 1087-1103. https://doi.org/10.1016/j.scitotenv.2019.06.412

Beyer, J., Green, N.W., Brooks, S., Allan, I.J., Ruus, A., Gomes, T., Bråte, I.L.N., Schøyen, M., 2017. Blue mussels (Mytilus edulis spp.) as sentinel organisms in coastal pollution monitoring: A $\begin{array}{lllll}\text { review. } & \text { Marine } & \text { Environmental } & \text { Research } & \text { 130, }\end{array}$ https://doi.org/10.1016/j.marenvres.2017.07.024

Binelli, A., Della Torre, C., Magni, S., Parolini, M., 2015. Does zebra mussel (Dreissena polymorpha) represent the freshwater counterpart of Mytilus in ecotoxicological studies? A critical review. Environmental Pollution 196, 386-403. https://doi.org/10.1016/j.envpol.2014.10.023

Binelli, A., Parolini, M., Cogni, D., Pedriali, A., Provini, A., 2009. A multi-biomarker assessment of the impact of the antibacterial trimethoprim on the non-target organism Zebra mussel (Dreissena polymorpha). Comparative Biochemistry and Physiology. C, Toxicology \& Pharmacology $150,329-336$.

Bourgeault, A., Gourlay-Francé, C., Vincent-Hubert, F., Palais, F., Geffard, A., BiagiantiRisbourg, S., Pain-Devin, S., Tusseau-Vuillemin, M., 2010. Lessons from a transplantation of zebra mussels into a small urban river: an integrated ecotoxicological assessment. Environmental toxicology $25,468-478$. 
Bradford, M.M., 1976. A rapid and sensitive method for the quantitation of microgram quantities of protein utilizing the principle of protein-dye binding. Analytical Biochemistry 72, 248254. https://doi.org/10.1016/0003-2697(76)90527-3

Brandão, F., Cappello, T., Raimundo, J., Santos, M.A., Maisano, M., Mauceri, A., Pacheco, M., Pereira, P., 2015. Unravelling the mechanisms of mercury hepatotoxicity in wild fish (Liza aurata) through a triad approach: bioaccumulation, metabolomic profiles and oxidative stress. Metallomics 7 , $1352-1363$.

Brew, D.W., Black, M.C., Santos, M., Rodgers, J., Henderson, W.M., 2020. Metabolomic Investigations of the Temporal Effects of Exposure to Pharmaceuticals and Personal Care Products and Their Mixture in the Eastern Oyster (Crassostrea virginica). Environmental Toxicology and Chemistry 39, 419-436. https://doi.org/10.1002/etc.4627

Brockmeier, E.K., Hodges, G., Hutchinson, T.H., Butler, E., Hecker, M., Tollefsen, K.E., Garcia-Reyero, N., Kille, P., Becker, D., Chipman, K., Colbourne, J., Collette, T.W., Cossins, A., Cronin, M., Graystock, P., Gutsell, S., Knapen, D., Katsiadaki, I., Lange, A., Marshall, S., Owen, S.F., Perkins, E.J., Plaistow, S., Schroeder, A., Taylor, D., Viant, M., Ankley, G., Falciani, F., 2017. The Role of Omics in the Application of Adverse Outcome Pathways for Chemical Risk Assessment. Toxicological Sciences 158, 252-262. https://doi.org/10.1093/toxsci/kfx097

Bundy, J.G., Davey, M.P., Viant, M.R., 2008. Environmental metabolomics: a critical review and future perspectives. Metabolomics 5, 3. https://doi.org/10.1007/s11306-008-0152-0

Cammen, L.M., Corwin, S., Christensen, J.P., 1990. Electron transport system (ETS) activity as a measure of benthic macrofaunal metabolism. Mar. Ecol. Prog. Ser 65, 171-182.

Campillo, J.A., Sevilla, A., González-Fernández, C., Bellas, J., Bernal, C., Cánovas, M., Albentosa, M., 2019. Metabolomic responses of mussel Mytilus galloprovincialis to fluoranthene exposure under different nutritive conditions. Marine Environmental Research 144, 194-202. https://doi.org/10.1016/j.marenvres.2019.01.012

Canesi, L., Viarengo, A., Leonzio, C., Filippelli, M., Gallo, G., 1999. Heavy metals and glutathione metabolism in mussel tissues. Aquatic Toxicology 46, 67-76. https://doi.org/10.1016/S0166-445X(98)00116-7

Cappello, T., 2020. NMR-Based Metabolomics of Aquatic Organisms, in: EMagRes. American Cancer Society, pp. 81-100. https://doi.org/10.1002/9780470034590.emrstm1604

Cappello, T., Fernandes, D., Maisano, M., Casano, A., Bonastre, M., Bebianno, M.J., Mauceri, A., Fasulo, S., Porte, C., 2017. Sex steroids and metabolic responses in mussels Mytilus galloprovincialis exposed to drospirenone. Ecotoxicology and Environmental Safety 143, 166-172. https://doi.org/10.1016/j.ecoenv.2017.05.031

Cappello, T., Mauceri, A., Corsaro, C., Maisano, M., Parrino, V., Lo Paro, G., Messina, G., Fasulo, S., 2013. Impact of environmental pollution on caged mussels Mytilus galloprovincialis using NMR-based metabolomics. Marine Pollution Bulletin 77, 132-139. https://doi.org/10.1016/j.marpolbul.2013.10.019

Cappello, T., Pereira, P., Maisano, M., Mauceri, A., Pacheco, M., Fasulo, S., 2016. Advances in understanding the mechanisms of mercury toxicity in wild golden grey mullet (Liza aurata) by $1 \mathrm{H}$ NMR-based metabolomics. Environmental Pollution 219, 139-148. https://doi.org/10.1016/j.envpol.2016.10.033

Caricato, R., Giordano, M.E., Schettino, T., Maisano, M., Mauceri, A., Giannetto, A., Cappello, T., Parrino, V., Ancora, S., Caliani, I., Bianchi, N., Leonzio, C., Mancini, G., Cappello, S., Fasulo, S., Lionetto, M.G., 2019. Carbonic anhydrase integrated into a multimarker approach for the detection of the stress status induced by pollution exposure in Mytilus galloprovincialis: A field case study. Science of The Total Environment 690, 140-150. https://doi.org/10.1016/j.scitotenv.2019.06.446

Catteau, A., Le Guernic, A., Marchand, A., Hani, Y.M.I., Palluel, O., Turiès, C., Bado-Nilles, A., Dedourge-Geffard, O., Geffard, A., Porcher, J.-M., 2019. Impact of confinement and food access restriction on the three-spined stickleback (Gasterosteus aculeatus, L.) during caging: a multi-biomarker approach. Fish Physiology and Biochemistry 45, 1261-1276. https://doi.org/10.1007/s10695-01900670-1

Chen, Z., Mayer, L.M., Weston, D.P., Bock, M.J., Jumars, P.A., 2002. Inhibition of digestive enzyme activities by copper in the guts of various marine benthic invertebrates. Environmental Toxicology and Chemistry: An International Journal 21, 1243-1248. 
Courant, F., Antignac, J.-P., Dervilly-Pinel, G., Le Bizec, B., 2014. Basics of mass spectrometry based metabolomics. Proteomics 14, 2369-2388. https://doi.org/10.1002/pmic.201400255

De Coen, WM., Janssen, C., 1997a. The use of biomarkers in Daphnia magna toxicity testing. IV. Cellular Energy Allocation: a new methodology to assess the energy budget of toxicant-stressed Daphnia populations. Journal of Aquatic Ecosystem Stress and Recovery 6, 43-55. https://doi.org/10.1023/a:1008228517955

De Coen, WM., Janssen, C., 1997b. The use of biomarkers in Daphnia magna toxicity testing II. Digestive enzyme activity in Daphnia magna exposed to sublethal concentrations of cadmium, chromium and mercury. Chemosphere 35, 1053-1067. https://doi.org/10.1016/S0045-6535(97)001720

De Coen, W.M., Janssen, C.R., Giesy, J., 2000. Biomarker applications in ecotoxicology: bridging the gap between toxicology and ecology, in: Persoone, G., Janssen, C., De Coen, W.M. (Eds.), New Microbiotests for Routine Toxicity Screening and Biomonitoring. Springer US, pp. 13-25.

De Zwaan, A., Dando, P., 1984. Phosphoenolpyruvate metabolism in bivalve molluscs. Molecular Physiology 5, 285-310.

Dedourge-Geffard, O., Palais, F., Biagianti-Risbourg, S., Geffard, O., Geffard, A., 2009. Effects of metals on feeding rate and digestive enzymes in Gammarus fossarum: An in situ experiment. Chemosphere 77, 1569-1576. https://doi.org/10.1016/j.chemosphere.2009.09.042

Dedourge-Geffard, O., Palais, F., Geffard, A., Amiard-Triquet, C., 2012. Origin of energy metabolism impairments. Ecological biomarkers-indicators of ecotoxicological effects. CRC Press, Taylor \& Francis Group, Boca Raton 279-306.

Dietz, T.H., Wilcox, S.J., Byrne, R.A., Lynn, J.W., Silverman, H., 1996. Osmotic and ionic regulation of North American zebra mussels (Dreissena polymorpha). American Zoologist 36, 364-372.

Digilio, G., Sforzini, S., Cassino, C., Robotti, E., Oliveri, C., Marengo, E., Musso, D., Osella, D., Viarengo, A., 2016. Haemolymph from Mytilus galloprovincialis: Response to copper and temperature challenges studied by $1 \mathrm{H}-\mathrm{NMR}$ metabonomics. Comparative Biochemistry and Physiology Part C: Toxicology \& Pharmacology 183, 61-71.

Dumas, T., Bonnefille, B., Gomez, E., Boccard, J., Castro, N.A., Fenet, H., Courant, F., 2020. Metabolomics approach reveals disruption of metabolic pathways in the marine bivalve Mytilus galloprovincialis exposed to a WWTP effluent extract. Science of The Total Environment 712, 136551. https://doi.org/10.1016/j.scitotenv.2020.136551

EEA, 2018. European waters-Assessment of status and pressures 2018 (No. 7/2018). European Environment Agency.

Fanslow, D.L., Nalepa, T.F., Johengen, T.H., 2001. Seasonal changes in the respiratory electron transport system (ETS) and respiration of the zebra mussel, Dreissena polymorpha in Saginaw Bay, Lake Huron. Hydrobiologia 448, 61-70. https://doi.org/10.1023/A:1017582119098

Forbes, V.E., Palmqvist, A., Bach, L., 2006. The use and misuse of biomarkers in ecotoxicology. Environmental Toxicology and Chemistry 25, 272-280. https://doi.org/10.1897/05-257R.1

Freitas, R., Leite, C., Pinto, J., Costa, M., Monteiro, R., Henriques, B., Di Martino, F., Coppola, F., Soares, A.M.V.M., Solé, M., Pereira, E., 2019. The influence of temperature and salinity on the impacts of lead in Mytilus galloprovincialis. Chemosphere 235, 403-412. https://doi.org/10.1016/j.chemosphere.2019.05.221

Gäde, G., Zebe, E., 1973. Über den Anaerobiosestoffwechsel von Molluskenmuskeln. Journal of comparative physiology 85, 291-301.

Hani, Y.M.I., Turies, C., Palluel, O., Delahaut, L., Gaillet, V., Bado-nilles, A., Porcher, J.-M., Geffard, A., Dedourge-geffard, O., 2018. Effects of chronic exposure to cadmium and temperature, alone or combined, on the threespine stickleback (Gasterosteus aculeatus): Interest of digestive enzymes as biomarkers. Aquatic Toxicology 199, 252-262.

Hines, A., Oladiran, G.S., Bignell, J.P., Stentiford, G.D., Viant, M.R., 2007. Direct sampling of organisms from the field and knowledge of their phenotype: key recommendations for environmental metabolomics. Environmental Science \& Technology 41, 3375-3381.

Isani, G., Cattani, O., Zurzolo, M., Pagnucco, C., Cortesi, P., 1995. Energy metabolism of the mussel, Mytilus galloprovincialis, during long-term anoxia. Comparative Biochemistry and Physiology Part B: Biochemistry and Molecular Biology 110, 103-113. 

graphical and interactive tool dedicated to 1D spectra processing for NMR-based metabolomics. Metabolomics 13, 36. https://doi.org/10.1007/s11306-017-1178-y

Ji, C., Cao, L., Li, F., 2015. Toxicological evaluation of two pedigrees of clam Ruditapes philippinarum as bioindicators of heavy metal contaminants using metabolomics. Environmental toxicology and pharmacology 39, 545-554.

Jones, O.A., Dondero, F., Viarengo, A., Griffin, J.L., 2008. Metabolic profiling of Mytilus galloprovincialis and its potential applications for pollution assessment. Marine Ecology Progress Series 369, 169-179.

Kalachova, K., Pulkrabova, J., Drabova, L., Cajka, T., Kocourek, V., Hajslova, J., 2011. Simplified and rapid determination of polychlorinated biphenyls, polybrominated diphenyl ethers, and polycyclic aromatic hydrocarbons in fish and shrimps integrated into a single method. Analytica Chimica Acta 707, 84-91. https://doi.org/10.1016/j.aca.2011.09.016

Karatayev, A., Claudi, R., Lucy, F., 2012. History of Dreissena research and the ICAIS gateway to aquatic invasions research. Aquatic Invasions.

Kerambrun, E., Palos Ladeiro, M., Bigot-Clivot, A., Dedourge-Geffard, O., Dupuis, E., Villena, I., Aubert, D., Geffard, A., 2016. Zebra mussel as a new tool to show evidence of freshwater contamination by waterborne Toxoplasma gondii. Journal of applied microbiology 120, 498-508.

Kim, Seonghye, Kim, A., Ma, S., Lee, W., Lee, S., Yoon, D., Kim, D.-H., Kim, Suhkmann, 2020. Glutathione Injection Alleviates the Fluctuation of Metabolic Response under Thermal Stress in Olive Flounder, Paralichthys olivaceus. Metabolites 10, 3.

Kwon, Y.-K., Jung, Y.-S., Park, J.-C., Seo, J., Choi, M.-S., Hwang, G.-S., 2012. Characterizing the effect of heavy metal contamination on marine mussels using metabolomics. Marine Pollution Bulletin 64, 1874-1879. https://doi.org/10.1016/j.marpolbul.2012.06.012

Lafontaine, Y. de, Gagné, F., Blaise, C., Costan, G., Gagnon, P., Chan, H.M., 2000. Biomarkers in zebra mussels (Dreissena polymorpha) for the assessment and monitoring of water quality of the St Lawrence River (Canada). Aquatic Toxicology 50, 51-71. https://doi.org/10.1016/S0166445X(99)00094-6

Le, A., Cooper, C.R., Gouw, A.M., Dinavahi, R., Maitra, A., Deck, L.M., Royer, R.E., Vander Jagt, D.L., Semenza, G.L., Dang, C.V., 2010. Inhibition of lactate dehydrogenase A induces oxidative stress and inhibits tumor progression. Proc Nat Acad Sci U S A 107, 2037-2042. https://doi.org/10.1073/pnas.0914433107

Le Guernic, A., Sanchez, W., Bado-Nilles, A., Palluel, O., Turies, C., Chadili, E., Cavalié, I., Delahaut, L., Adam-Guillermin, C., Porcher, J.-M., Geffard, A., Betoulle, S., Gagnaire, B., 2016. In situ effects of metal contamination from former uranium mining sites on the health of the three-spined stickleback (Gasterosteus aculeatus, L.). Ecotoxicology 25, 1234-1259. https://doi.org/10.1007/s10646016-1677-z

Lee, A.-C., Lee, K.-T., 2011. The enzyme activities of opine and lactate dehydrogenase in the gills, mantle, foot, and adductor of the hard clam Meretrix lusoria. J Mar Sci Technol 19, 361-367.

Leprêtre, M., Almunia, C., Armengaud, J., Salvador, A., Geffard, A., Palos-Ladeiro, M., 2019. The immune system of the freshwater zebra mussel, Dreissena polymorpha, decrypted by proteogenomics of hemocytes and plasma compartments. Journal of Proteomics 202, 103366. https://doi.org/10.1016/j.jprot.2019.04.016

Lin, C.Y., Viant, M.R., Tjeerdema, R.S., 2006. Metabolomics: methodologies and applications in the environmental sciences. Journal of Pesticide Science 31, 245-251.

Louis, F., Devin, S., Giambérini, L., Potet, M., David, E., Pain-Devin, S., 2019. Energy allocation in two dreissenid species under metal stress. Environmental Pollution 245, 889-897. https://doi.org/10.1016/j.envpol.2018.11.079

Lundebye, A.-K., Langston, W., Depledge, M., 1997. Stress proteins and condition index as biomarkers of tributyltin exposure and effect in mussels. Ecotoxicology 6, 127-136.

Madon, S.P., Schneider, D.W., Stoeckel, J.A., Sparks, R.E., 1998. Effects of inorganic sediment and food concentrations on energetic processes of the zebra mussel, Dreissena polymorpha: implications for growth in turbid rivers. Canadian journal of fisheries and aquatic sciences 55, 401-413.

Maisano, M., Cappello, T., Natalotto, A., Vitale, V., Parrino, V., Giannetto, A., Oliva, S., Mancini, G., Cappello, S., Mauceri, A., Fasulo, S., 2017. Effects of petrochemical contamination on 
caged marine mussels using a multi-biomarker approach: Histological changes, neurotoxicity and $\begin{array}{lllll}\text { hypoxic stress. Marine Environmental Research 128, 123. } & \text { 114 }\end{array}$ https://doi.org/10.1016/j.marenvres.2016.03.008

McMahon, R.F., 1996. The physiological ecology of the zebra mussel, Dreissena polymorpha, in North America and Europe. American Zoologist 36, 339-363.

Milinkovitch, T., Geffard, O., Geffard, A., Mouneyrac, C., Chaumot, A., Xuereb, B., Fisson, C., Minier, C., Auffret, M., Perceval, O., Egea, E., Sanchez, W., 2019. Biomarkers as tools for monitoring within the Water Framework Directive context: concept, opinions and advancement of expertise. Environmental Science and Pollution Research 26, 32759-32763. https://doi.org/10.1007/s11356-019-06434-x

Minguez, L., Boiché, A., Sroda, S., Mastitsky, S., Brulé, N., Bouquerel, J., Giambérini, L., 2012. Cross-effects of nickel contamination and parasitism on zebra mussel physiology. Ecotoxicology 21, 538-547.

Minier, C., Abarnou, A., Jaouen-Madoulet, A., Le Guellec, A.-M., Tutundjian, R., Bocquené, G., Leboulenger, F., 2006. A pollution-monitoring pilot study involving contaminant and biomarker measurements in the Seine Estuary, France, using zebra mussels (Dreissena polymorpha). Environmental Toxicology and Chemistry 25, 112-119. https://doi.org/10.1897/05-161R.1

Nam, K.-H., Kim, Y.-J., Moon, Y.S., Pack, I.-S., Kim, C.-G., 2017. Salinity affects metabolomic profiles of different trophic levels in a food chain. Science of The Total Environment 599-600, 198206. https://doi.org/10.1016/j.scitotenv.2017.05.003

Navarro, E., Bacardit, M., Caputo, L., Palau, T., Armengol, J., 2006. Limnological characterization and flow patterns of a three-coupled reservoir system and their influence on Dreissena polymorpha populations and settlement during the stratification period. Lake and Reservoir Management 22, 293-302.

Nguyen, T.V., Alfaro, A.C., 2020. Applications of omics to investigate responses of bivalve haemocytes to pathogen infections and environmental stress. Aquaculture 518, 734488. https://doi.org/10.1016/j.aquaculture.2019.734488

Nguyen, Thao V, Alfaro, A.C., Merien, F., Lulijwa, R., Young, T., 2018. Copper-induced immunomodulation in mussel (Perna canaliculus) haemocytes. Metallomics 10, 965-978.

Nguyen, Thao V., Alfaro, A.C., Merien, F., Young, T., Grandiosa, R., 2018. Metabolic and immunological responses of male and female new Zealand Greenshell ${ }^{\mathrm{TM}}$ mussels (Perna canaliculus) infected with Vibrio sp. Journal of Invertebrate Pathology 157, 80-89. https://doi.org/10.1016/j.jip.2018.08.008

Nicolè, F., Thomas, O.P., 2017. - Metabolomique- Prospectives de l'institut Ecologie \& Environment du CNRS. https://doi.org/DOI: 10.13140/RG.2.2.13628.74889

Palais, F., Dedourge-Geffard, O., Beaudon, A., Pain-Devin, S., Trapp, J., Geffard, O., Noury, P., Gourlay-Francé, C., Uher, E., Mouneyrac, C., Biagianti-Risbourg, S., Geffard, A., 2012. One-year monitoring of core biomarker and digestive enzyme responses in transplanted zebra mussels (Dreissena polymorpha). Ecotoxicology 21, 888-905. https://doi.org/10.1007/s10646-012-0851-1

Péden, R., Poupin, P., Sohm, B., Flayac, J., Giambérini, L., Klopp, C., Louis, F., Pain-Devin, S., Potet, M., Serre, R.-F., 2019. Environmental transcriptomes of invasive dreissena, a model species in ecotoxicology and invasion biology. Scientific data 6, 1-8.

Plaistow, S.J., Bollache, L., Cézilly, F., 2003. Energetically costly precopulatory mate guarding in the amphipod Gammarus pulex: causes and consequences. Animal Behaviour 65, 683-691. https://doi.org/10.1006/anbe.2003.2116

Prud'homme, S.M., Hani, Y.M.I., Cox, N., Lippens, G., Nuzillard, J.-M., Geffard, A., 2020. The Zebra Mussel (Dreissena polymorpha) as a Model Organism for Ecotoxicological Studies: A Prior 1H NMR Spectrum Interpretation of a Whole Body Extract for Metabolism Monitoring. Metabolites $10,256$.

Prud'homme, S.M., Hani, Y.M.I., Cox, N., Lippens, G., Nuzillard, J.-M., Geffard, A., Submitted. The zebra mussel (Dreissena polymorpha) as a model organism for ecotoxicological studies: a prior $1 \mathrm{H}$ NMR spectrum interpretation of a whole body extract for metabolism monitoring. Metabolites.

Quinn, B., Schmidt, W., O'Rourke, K., Hernan, R., 2011. Effects of the pharmaceuticals gemfibrozil and diclofenac on biomarker expression in the zebra mussel (Dreissena polymorpha) and 
their comparison with standardised toxicity tests. Chemosphere 84, 657-663. https://doi.org/10.1016/j.chemosphere.2011.03.033

Rist, S.E., Assidqi, K., Zamani, N.P., Appel, D., Perschke, M., Huhn, M., Lenz, M., 2016. Suspended micro-sized PVC particles impair the performance and decrease survival in the Asian green mussel Perna viridis. Marine Pollution Bulletin 111, 213-220. https://doi.org/10.1016/j.marpolbul.2016.07.006

Sanchez, W., Porcher, J.M., 2009. Fish biomarkers for environmental monitoring within the water framework directive. Trends Anal Chem 28. https://doi.org/10.1016/j.trac.2008.10.012

Slooff, W., de Zwart, D., Marquenie, J., 1983. Detection limits of a biological monitoring system for chemical water pollution based on mussel activity. Bulletin of Environmental Contamination and Toxicology 30, 400-405.

Tikunov, A.P., Johnson, C.B., Lee, H., Stoskopf, M.K., Macdonald, J.M., 2010. Metabolomic investigations of American oysters using 1H-NMR spectroscopy. Marine drugs 8, 2578-2596.

Tuffnail, W., Mills, G.A., Cary, P., Greenwood, R., 2009. An environmental 1H NMR metabolomic study of the exposure of the marine mussel Mytilus edulis to atrazine, lindane, hypoxia and starvation. Metabolomics 5, 33-43. https://doi.org/10.1007/s11306-008-0143-1

van Vliet, M.T.H., Zwolsman, J.J.G., 2008. Impact of summer droughts on the water quality of the Meuse river. Journal of Hydrology 353, 1-17. https://doi.org/10.1016/j.jhydrol.2008.01.001

Verslycke, T., Roast, S.D., Widdows, J., Jones, M.B., Janssen, C.R., 2004. Cellular energy allocation and scope for growth in the estuarine mysid Neomysis integer (Crustacea: Mysidacea) following chlorpyrifos exposure: a method comparison. Journal of Experimental Marine Biology and Ecology 306, 1-16. https://doi.org/10.1016/j.jembe.2003.12.022

Viant, M.R., 2007. Metabolomics of aquatic organisms: the new 'omics' on the block. Marine Ecology Progress Series 332, 301-306.

Wang, T., Long, X., Cheng, Y., Liu, Z., Yan, S., 2015. A Comparison Effect of Copper Nanoparticles versus Copper Sulphate on Juvenile Epinephelus coioides: Growth Parameters, Digestive Enzymes, Body Composition, and Histology as Biomarkers. International Journal of Genomics 2015, 783021. https://doi.org/10.1155/2015/783021

Watanabe, M., Meyer, K.A., Jackson, T.M., Schock, T.B., Johnson, W.E., Bearden, D.W., 2015. Application of NMR-based metabolomics for environmental assessment in the Great Lakes using zebra mussel (Dreissena polymorpha). Metabolomics 11, 1302-1315. https://doi.org/10.1007/s11306-0150789-4

Wernersson, A.-S., Carere, M., Maggi, C., Tusil, P., Soldan, P., James, A., Sanchez, W., Dulio, V., Broeg, K., Reifferscheid, G., Buchinger, S., Maas, H., Van Der Grinten, E., O’Toole, S., Ausili, A., Manfra, L., Marziali, L., Polesello, S., Lacchetti, I., Mancini, L., Lilja, K., Linderoth, M., Lundeberg, T., Fjällborg, B., Porsbring, T., Larsson, D.J., Bengtsson-Palme, J., Förlin, L., Kienle, C., Kunz, P., Vermeirssen, E., Werner, I., Robinson, C.D., Lyons, B., Katsiadaki, I., Whalley, C., den Haan, K., Messiaen, M., Clayton, H., Lettieri, T., Carvalho, R.N., Gawlik, B.M., Hollert, H., Di Paolo, C., Brack, W., Kammann, U., Kase, R., 2015. The European technical report on aquatic effect-based monitoring tools under the water framework directive. Environmental Sciences Europe 27, 7. https://doi.org/10.1186/s12302-015-0039-4

Wright, S.L., Thompson, R.C., Galloway, T.S., 2013. The physical impacts of microplastics on marine organisms: a review. Environmental pollution 178, 483-492.

Wu, H., Wang, W.-X., 2011. Tissue-specific toxicological effects of cadmium in green mussels (Perna viridis): Nuclear magnetic resonance-based metabolomics study. Environmental Toxicology and Chemistry 30, 806-812. https://doi.org/10.1002/etc.446

Wu, H., Wang, W.-X., 2010. NMR-based metabolomic studies on the toxicological effects of cadmium and copper on green mussels Perna viridis. Aquatic Toxicology 100, 339-345. https://doi.org/10.1016/j.aquatox.2010.08.005

Xu, L., Lu, Z., Ji, C., Cong, M., Li, F., Shan, X., Wu, H., 2019. Toxicological effects of As (V) in juvenile rockfish Sebastes schlegelii by a combined metabolomic and proteomic approach. Environmental Pollution 255, 113333. https://doi.org/10.1016/j.envpol.2019.113333

Zurburg, W., De Zwaan, A., 1981. The role of amino acids in anaerobiosis and osmoregulation in bivalves. Journal of Experimental Zoology 215, 315-325. https://doi.org/10.1002/jez.1402150309 